\title{
Melkersson Rosenthal Sendromu Klinik ve Etiyolojik Özellikleri: 3 Olgu Sunumu
}

\section{Clinical and Etiological Characteristics of Melkersson}

\section{Rosenthal Syndrome: 3 Case Reports \\ Fettah Eren', Güllü Eren², Recep Aygü|3}

'Sağlık Bilimleri Üniversitesi, Konya Eğitim ve Araşırma Hastanesi, Nöroloji Kliniği, Konya

${ }^{2}$ Necmettin Erbakan Üniversitesi, Meram Tıp Fakültesi, Halk Sağlığı Anabilim Dalı, Konya

${ }^{3}$ Selçuk Üniversitesi Tıp Fakültesi, Nöroloji Anabilim Dalı, Konya

Yazışma Adresi / Correspondence:

Fettah Eren

Sağlık Bilimleri Üniversitesi, Konya Eğitim ve Araştırma Hastanesi, Nöroloji Kliniği

T: +90 $3322244407 \quad$ E-mail: dreren42@hotmail.com

Geliş Tarihi / Received : 26.07.2018 Kabul Tarihi / Accepted : 06.09.2018

Melkersson Rosenthal Sendromunun Özellikleri/ Characteristics of Melkersson Rosenthal Syndrome

Bilgilerin bilimsel ortamlarda paylaşılması için hasta onamları alınmıştır.

Kasım 2017'de, 53. ulusal nöroloji kongresinde e-poster olarak sunulmuştur.

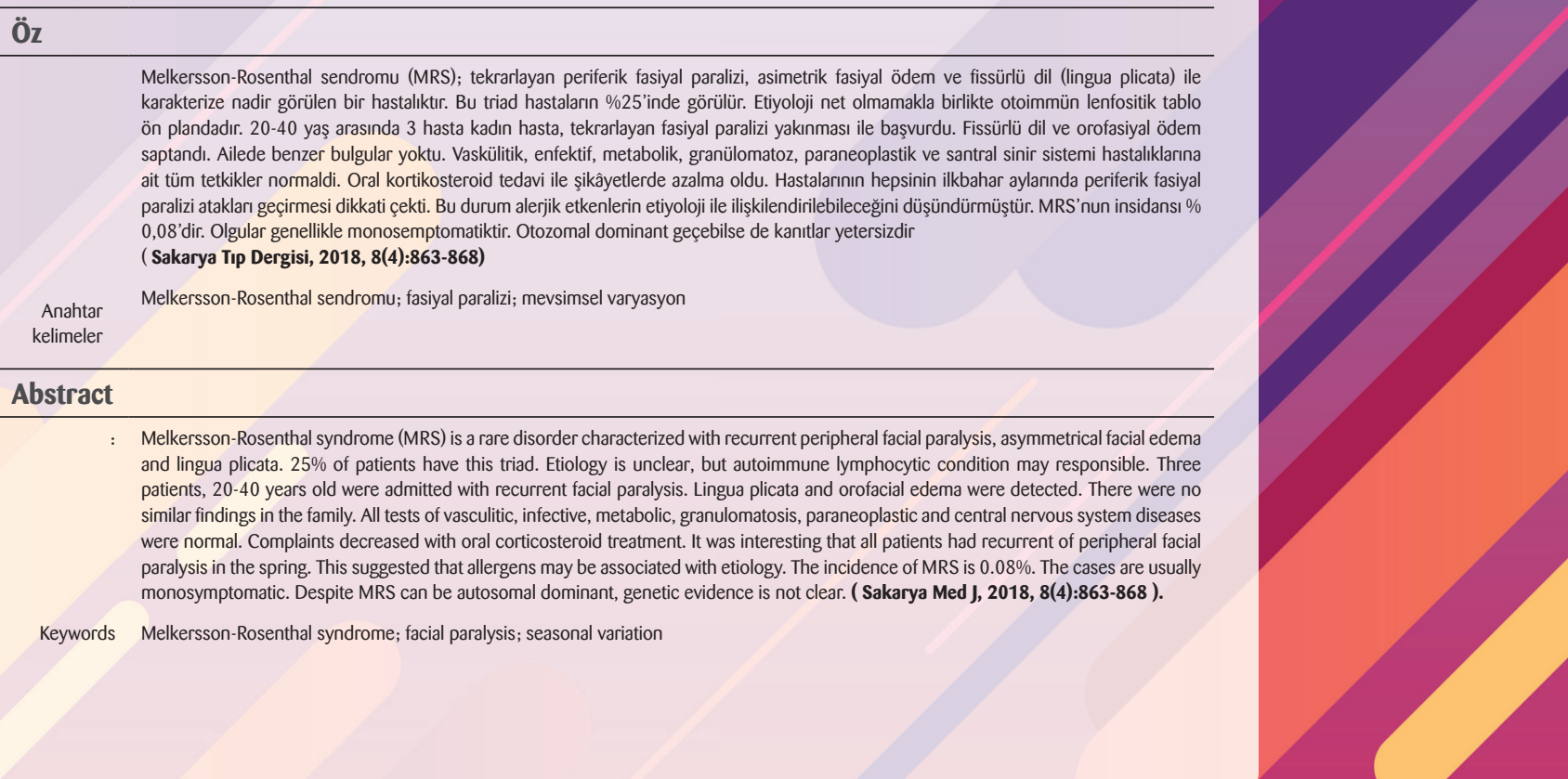


Sakarya TIp Dergisi 2018;8(4):863-868

EREN ve Ark elkersson Rosenthal Sendromu Klinik ve Etiyolojk Özellikleri: 3 Olgu Sunumı

\section{Giriş}

Melkersson-Rosenthal sendromu (MRS) tekrarlayan periferik fasiyal paralizi, ağrısız ve gode bırakmayan orofasiyal ödem ve fissürlü dil (lingua plicata) özellikleri ile karakterize bir hastalıktır. Bu triadın tüm özelliklerinin birlikte görülmesi oldukça nadirdir. Genellikle monosemptomatik ya da oligosemptomatik tutulum saptanır. En sık bulgu orofasiyal ödemdir. Hastaların yalnızca \%3040'ında fissürlü dil görülür. 25-40 yaş arası kadınlarda daha sıktır. ${ }^{1}$

Hastalığın tanısı klinik bulgular ile konulmaktadır. Ancak ödemli mukozadan alınan biyopsi materyalinde non-kazeifiye epiteloid hücreli granülomlar, mononükleer hücre infiltrasyonu, Langerhans tipi dev hücreler, non-spesifik inflamasyon ve fibrozis olması tanıyı desteklemektedir. ${ }^{1}$ Etiyolojiden adenotonsillit, herpes simpleks virüs (HSV) enfeksiyonu, tüberküloz, T lenfosit fonksiyon bozukluğu, alerjik hastalıklar, atopi ve genetik faktörler sorumlu tutulmuştur. Ancak bu durumların hiçbiri kesin etiyoloji ile ilişkilendirilememiştir. ${ }^{2,3}$ Tedavide kortikosteroidler, antihistaminikler, immünsupresif tedaviler, danazol, klofazimin ve antibiyotikler kullanılmaktadır. ${ }^{4}$ Belirti ve bulguların büyük çoğunluğu medikal tedaviler ile gerilemektedir. Bu tedavilere yeterli cevap alınmaması durumunda fasiyal sinir dekompresyonu yapılmaktadır. ${ }^{5}$

Bu üç olgu sunumu ile MRS'nun klinik özellikleri, ayırıcı tanısı ve periferik fasiyal paralizinin ilkbahar aylarında ortaya çıkmasının etiyoloji ile ilişkisi değerlendirilmiştir.

\section{Olgu sunumları}

\section{Olgu 1}

22 yaşında kadın hasta, 1 haftadır olan sağ yüz yarımında uyuşma ve hareketlerde yavaşlama yakınması ile başvurdu. Öyküsünden 3 yı önce ve 1 ay önce mart aylarında sol periferik fasiyal paralizi geçirdiği, 10 gün süre ile oral kortikosteroid tedavi kullandığı öğrenildi. Nörolojik muayenesi, sağda hafif periferik fasiyal sinir lezyonu bulguları dışında normaldi. Sol yüz yarımındaki minimal orofasiyal ödem ve dildeki fissür artışı dikkat çekti (Resim 1).
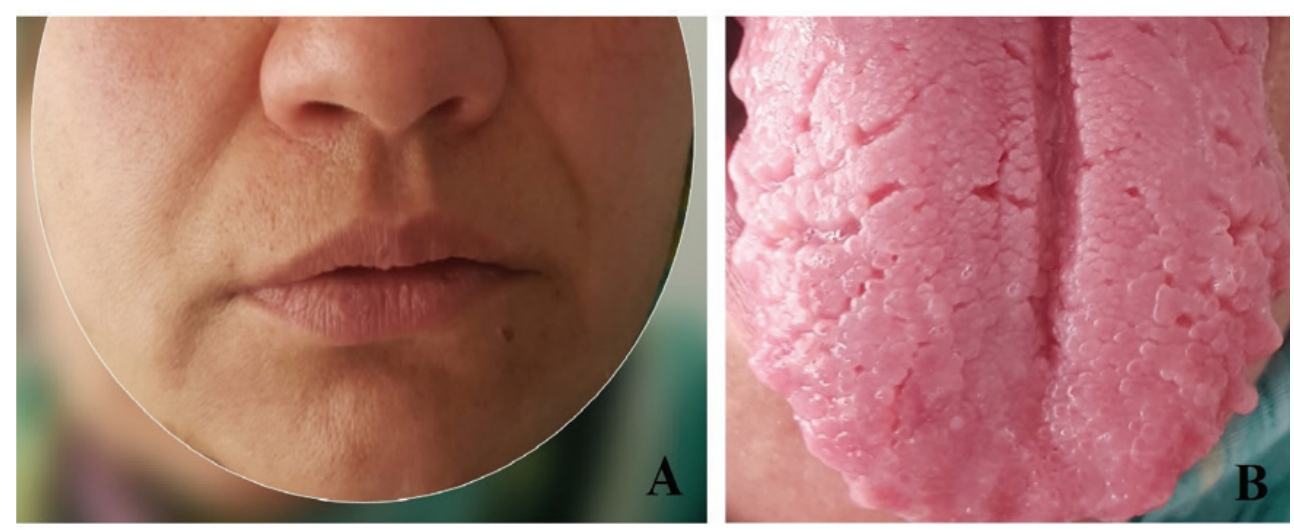

Resim 1. A) Sağda hafif nazolabial oluk silikliği, sol yüz yarımında minimal orofasiyal ödem B) Dilde fissür artışı (lingua plicata)

Vital bulgularından ateşi $36,8^{\circ} \mathrm{C}$ ve kan basıncı $120 / 70 \mathrm{mmHg}$ idi. Kan laboratuvar tetkiklerinde beyaz küre $(\mathrm{WBC})=7,8 \mathrm{~K} / \mathrm{uL}(3,5-10,5)$, hemoglobin=11,8 g/dL $(13,5-17,5)$, trombosit=250 K/uL (150-450), B12=214,4 pg/mL (191-663), folik asit=10,4 ng/mL (3,1- 17,5) bulundu. Kan şekeri=98 mg/dL (70-110), üre=27 mg/dL (18-55), HbA1C=5,4 (4-6) olarak belirlendi. C-reaktif 
protein $(C R P)=6,7 \mathrm{mg} / \mathrm{L}(0-5)$ ve sedimantasyon= $17 \mathrm{~m} / \mathrm{h}(0-20)$ idi. Tiroid stimüle edici hormon $(\mathrm{TSH})=2,37 \mu \mathrm{lU} / \mathrm{mL}(0,56-5,57)$, serbest $\mathrm{T} 3, \mathrm{~T} 4$, tiroglobulin ve tiroid oto antikorları normaldi. Karaciğer fonksiyon testleri, kreatinin fosfokinaz, anjiotensin dönüştürücü enzim (ACE), elektrolitler ve kan gazı normal sınılardaydı. CA-125=10,5 U/mL (0-35), CA 15.3=10,74 U/mL (0-25), CA 19.9=15,06 U/mL (0-39) ve CEA=1,57 ug/L (0-10000) olarak belirlendi. Vaskülitik, enfektif ve granülomatöz hastalıkların değerlendirmesi için istenen diğer kan testleri normaldi. Tüberkülin cilt testi (PPD) negatifti. Direkt akciğer grafisi, batın ultrasonografi (USG), beyin-kulak manyetik rezonans görüntüleme (MRG) ve beyin MRG anjiyografi normaldi. Odyolojik değerlendirmede patoloji saptanmadı. 2 haftada oral kortikosteroid tedavi azaltılarak kesildi. Bir ay sonraki kontrolünde semptomların azalmış olduğu, 3 ay sonraki kontrolünde ise fasiyal asimetrinin tama yakın düzeldiği öğrenildi.

\section{Olgu 2}

33 yaşında kadın hasta, 3 gün önce başlayan sol yüz yarımında hareket azlı̆ı ve uyuşma yakınması ile başvurdu. Öyküsünden 1 yıl önce nisan ayında, sol periferik fasiyal paralizi geçirdiği ve oral kortikosteroid tedavi aldığı öğrenildi. Nörolojik muayenesi solda hafif periferik fasiyal paralizi bulguları dışında normaldi. Sağ yüz yarımındaki minimal orofasiyal ödem ve dilde fissür artışı görüldü (Resim 2).
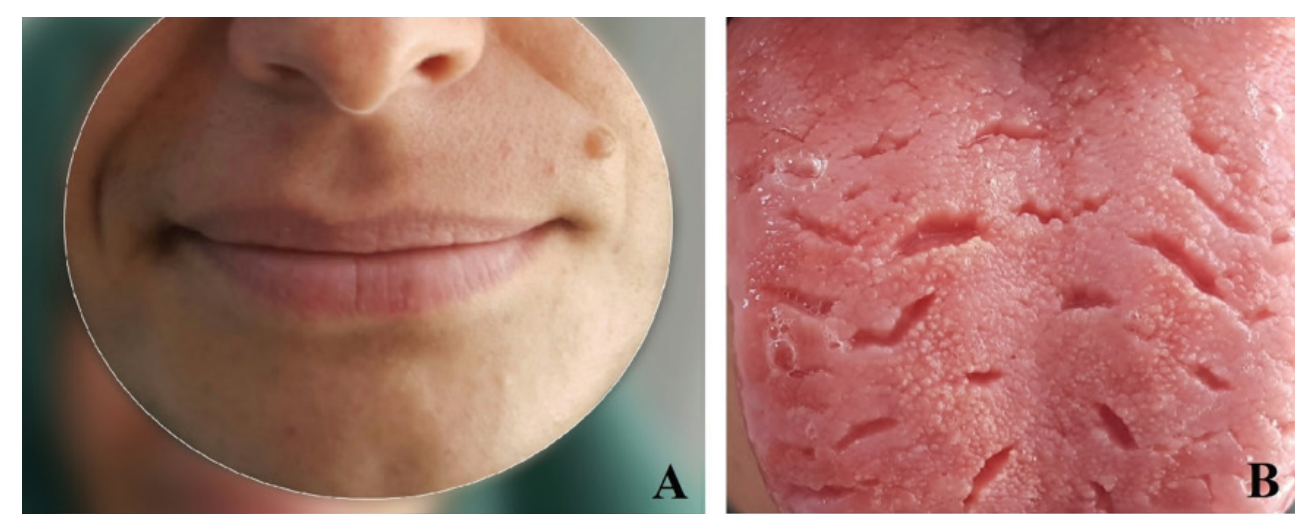

Resim 2. A) Solda hafif nazolabial oluk silikliği, sağ yüz yarımında minimal orofasiyal ödem B) Dilde fissür artışı (lingua plicata)

Vital bulguları normaldi. Kan tetkiklerinde beyaz küre $(\mathrm{WBC})=12,8 \mathrm{~K} / \mathrm{uL}(3,5-10,5)$, hemoglobin=10,8 g/dL (13,5-17,5), trombosit=250 K/uL (150-450), B12=190,4 pg/mL (191-663), folik asit=10,4 ng/mL $(3,1-17,5)$ bulundu. C-reaktif protein (CRP) $=10,7 \mathrm{mg} / \mathrm{L}(0-5)$ ve sedimantasyon=21 m/h (0-20) idi. Birinci olguya yapılan benzer kan tetkikleri, odyolojik değerlendirme ve beyin MRG incelemeleri normaldi. Kortikosteroid tedavi 10 günde azaltılarak kesildi. 15 gün sonra şikayetlerinin kısmen azaldığı, 3 ay sonraki kontrolünde ise fasiyal asimetrinin tamamen düzeldiği öğrenildi.

\section{Olgu 3}

43 yaşında kadın hasta, 5 gün önce başlayan sağ yüz yarımında hareketlerde yavaşlama yakınması ile başvurdu. Öyküsünden 10 yıl önce ilkbaharda ve 3 yıl önce mart ayında sol periferik fasiyal paralizi geçirdiği ve tedavi almadan düzeldiği öğrenildi. Nörolojik muayenede sağ periferik fasiyal sinir lezyonu bulguları vardı. Derin tendon refleksleri hipoaktif idi. Sağ yüz yarımında orofasiyal ödem ve dilde fissür artışı belirlendi (Resim 3). Vital bulguları normaldi. Kan tetkiklerinde
Sakarya Tıp Dergisi $2018 ; 8(4): 863-868$

EREN ve Ark.

Melkersson Rosenthal Sendromu Klinik ve Etiyolojik Özellikleri: 3 Olgu Sunumu 
Sakarya TIp Dergisi 2018;8(4):863-868

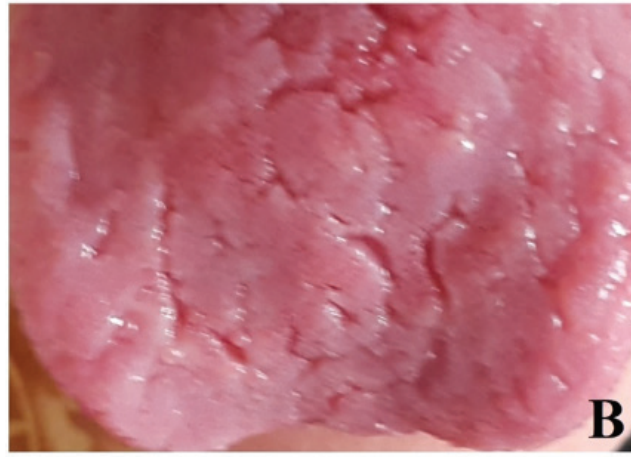

Resim 3. A) Sağda nazolabial oluk silikliği, sağ yüz yarımında orotasiyal ödem B) Dilde tissür artışı (lingua plicata)

\section{Tartışma}

MRS nadir görülen bir hastalıktır. İnsidansı \% 0,08 olarak tespit edilmiştir. 20-40 yaş arasında kadınlarda daha sıktır. ${ }^{1,4}$ Rekürrens periferik paraliziye, orofasiyal ödem ve fissürlü dil eşlik etmektedir. Monosemptomatik ya da oligosemptomatik olmaları daha yaygındır. ${ }^{1}$ Bu üç kriterin birlikteliği hastaların \% 25 'inde vardır. ${ }^{6}$ Rekürrens fasiyal paralizi Bell paralizisine benzemektedir. Hastaların \%47-90'ında vardır. Fasiyal tutulum tek taraflı olabileceği gibi çift taraflı ve kalıcı da olabilir. Fasiyal tuluma 9. ve 11. kraniyal sinir tutulumu da eşlik edebilir. ${ }^{7}$ Ayırıcı tanıda sifiliz, lösemi, Guillain- Barre sendromu, herpes zoster, otitis media, multipl skleroz, diabetes mellitus, myastenia graves, poliarteritis nodosa (PAN), lösemi ve tümörler yer almaktadır. ${ }^{1}$ Bu hastalıklara ait klinik değerlendirmeler, kan tetkikileri ve radyolojik incelemeler bizim hastalarımıza da yapılmıştır. 3. olguda insidental saptanan iskemik gliotik lezyonlar dışında patolojik radyolojik bulgu tespit edilmemiştir. Ayrıca ikinci ve üçüncü olguda hafif lökositoz, sedimantasyon ve CRP'de hafif yükseklik saptanmıştır. Bunlar non-spesifik bulgular olarak değerlendirilmiştir.

Orofasiyal ödem fasiyal paraliziden daha sık görülmektedir. Tek tarafll, özellikle üst dudak ve ağız çevresinde, gode bırakmayan ve ağrısız bir ödemle karakterizedir. Atak sıklığı arttıkça fibrozis ve yumuşak doku hiperplazisi ile orofasiyal ödem sıklığı da artmaktadır. ${ }^{8}$ Hastalarımızdan üçüncü olguda daha belirgin orofasiyal ödem olduğu görülmüştür. Bu durum uzun hastalık sürecine, atak sayısının fazlalğına ve kortikosteroid tedavi almamaya bağlanmıştır. Fissürlü dil ise orofasiyal ödem ve rekürrens fasiyal paralizinin beraber olduğu hastalarda daha nadirdir. Hastaların sadece \%40'ında görülür. Özellikle dilin 2/3 ön kısmını etkiler. ${ }^{9}$ Hastalarımızın hepsinde dilde fissür artışı olduğu görülmüştür.

MRS kesin tanısı için kullanılacak radyolojik ve histopatolojik inceleme yöntemi bulunmamaktadır. Tanı özellikle klinik bulgular doğrultusunda konulmaktadır. Biyopside non-kazeöz granülomatöz kellit varlığı tanıyı desteklemektedir. Ancak biyopsinin normal olması tanıyı dışlamamaktadır. ${ }^{1}$ Has- 
talarımızın klinik özellikleri MRS varlığını desteklemiştir. Rekürrens fasiyal paralizi yapabilecek diğer nedenler de ekarte edilmiştir. Bulgular MRS tanısı için yeterli bulunmuştur. Hastalarımıza durumları anlatıldığında biyopsi istemediklerini beyan etmişlerdir.

MRS hastalığının etiyolojisi tam olarak bilinmemektedir. Başta HSV olmak üzere bakteriyel ve viral nedenler, granülamatöz hastalıklar, katkı maddeleri, proteinler ve ağır metallere karşı gelişen hipersensitivite, genetik yatkınlık ve birçok otoimmün hastalık sorumlu tutulmaktadır. ${ }^{2,3,10}$ Ayrıca migren, anjioödem, rekürrens erizipel, lenfoma, trigeminal nevralji, amiloidozis, hipotiroidizm, hiperplastik gingivitis, otoskleroz ve vena cava superior obstrüksiyonu ile birlikteliği de bildirilmiş̧ir. ${ }^{2}$ Hastalarımızda MRS ile birlikte başka hastalık tespit edilmemiştir. Ayrıca periferik fasiyal paralizi ataklarının ilkbahar aylarında olması dikkat çekmiştir. Alerjik hastalıkların ilkbahar aylarında indüklendiği bilinmektedir. Bu durum etiyoloji ile ilişkilendirildiğinde, alerjik mekanizmaların periferik fasiyal paraliziyi tetikleyebileceğini düşündürmüştür.

MRS'nun tedavisinde kortikosteroidler kullanılmaktadır. Bu tedavi doku ödemini ve inflamasyonu azaltmaktadır. Tedaviye iyi cevap vermeyen hastalara metotreksat, dapson, sulfasalazin, klofazimin, danazol, difenhidramin, penisilin, hidroklorokin, eritromisin, minoksilin, tetrasiklin ve klindamisin verilmektedir. Medikal tedavinin yetersiz kalması durumunda fasiyal sinir dekompresyonu ve keiloplasti cerrahisi uygulanmaktadır. ${ }^{4,5}$ Hastalarımı kortikosteroid tedavisi ile düzelmekte olduğu için diğer medikal ve cerrahi tedavilere ihtiyaç duyulmamıştır.

Sonuç olarak, rekürrens fasiyal paralizinin etiyolojisinde MRS da düşünülmesi gereken bir hastalıktır. Hastalık nadir görüldüğü için sıkııla tanınması gecikmektedir. Benzer tabloyu meydana getiren birç̧ok hastalık olduğu için ayırıcı tanı dikkatlice gözden geçirilmelidir. Bu üç olgunun da periferik fasiyal paralizi ataklarının ilkbahar aylarında gelişmiş olması etiyolojide alerjik özelliklerin de sorgulanmasının önemli olduğunu göstermektedir.
Sakarya Tip Dergisi

$2018 ; 8(4): 863-868$ 
1. Ziem PE, Pfrommer C, Goerdt S, Orfanos CE, Blume Peytavi U. Melkersson-Rosenthal syndrome in childhood: a challenge in differential diagnosis and treatment. Br J Dermatol. 2000;143:860-863.

2. Micheal S, Sara P, Henry S. Melkersson-Rosenthal syndrome in the perioculer area: A review of the literature and case report. Ann Plastic Surg 2003;150:664-668.

3. Apaydin R, Bilen N, Bayramgurler D, Efendi H, Vahaboglu H. Detection of Mycobacterium tuberculosis DNA in a patient with MelkerssonRosenthal syndrome using polymerase chain reaction. $\mathrm{Br}$ J Dermatol. 2000;142:1251-1252.

4. Kesler A, Vainstein G, Gadot N. Melkersson-Rosenthal syndrome treated by methylprednisolone. Neurology 1998;51:1440-1441.

5. Kruse-Losler B, Presser D, Metze D, Joos U. Surgical tre-atment of persistent macrocheilia in patients with Melkersson-Rosenthal syndrome and cheilitis granuloma-tosa. Arch Dermatol. 2005;141:1085-1091.
6. Akdağ M, Özkurt FE, Yilmaz B, Topçu I, Meriç F. Bilateral ve tekrarlayan fasiyal paralizinin nadir nedeni: Melkersson-Rosenthal sendromu. Dicle Tip Dergisi 2015;42:102-106

7. Khandpur S, Malhotra AK, Khanna N. Melkersson-Rosenthal syndrome with diffuse facial swelling and multiple cranial nerve palsies. J Dermatol. 2006;33:411-414.

8. Sciubba JJ, Said-Al-Naief N. Orofacial granulomatosis: presentation, pathology and management of 13 cases. J Oral Pathol Med. 2003;32:576 585

9. Cockerham KP, Hidayat AA, Cockerham GC, Depper M, Sorensen S, Cytyrn AS, et al. Melkersson-Rosenthal syndrome: new clinicopathologic findings in 4 cases. Arch Ophthalmol. 2000;118:227-232.

10. Jasinska $D$, Boczon J. Melkersson-Rosenthal syndrome as an early manifestation of mixed connective tissue disease. European journal of medical research 2015;20:100. 